\title{
Response of Bread Wheat (Triticum aestivum L.) to Potassium (K) and Blended NPS Fertilizer Rates in the Nitisols of Southern Ethiopia
}

\author{
Tigist Tesfaye, Fanuel Laekemariam, and Abera Habte \\ Department of Plant Sciences, Wolaita Sodo University, P.O. Box 138, Wolaita Sodo, Ethiopia \\ Correspondence should be addressed to Abera Habte; habteee@gmail.com
}

Received 31 May 2020; Revised 24 February 2021; Accepted 21 June 2021; Published 30 June 2021

Academic Editor: Durgesh Jaiswal

Copyright (C) 2021 Tigist Tesfaye et al. This is an open access article distributed under the Creative Commons Attribution License, which permits unrestricted use, distribution, and reproduction in any medium, provided the original work is properly cited.

\begin{abstract}
Wheat is the most important cereal crop ranking $4^{\text {th }}$ in total grain production and area coverage in Ethiopia. However, its productivity is low compared to the yield obtained under the research station. Multinutrient deficiency, low/no chemical fertilizer usage, and poor management practices are among the major constraints. Thus, response of bread wheat to NPS and K fertilizer rates was evaluated in the nitisols at Kokate, Wolaita Sodo, Southern Ethiopia, in 2016. Four rates of $\mathrm{KCl}(0-0-60)(0,25,50$, and $\left.75 \mathrm{~kg} \cdot \mathrm{ha}^{-1}\right)$ and five blended NPS $\left(19 \mathrm{~N}-38 \mathrm{P}_{2} \mathrm{O}_{5}-7 \mathrm{~S}\right)$ rates $\left(0,50,100,150\right.$, and $\left.200 \mathrm{~kg} \cdot \mathrm{ha}^{-1}\right)$ were investigated using randomized complete block design with factorial arrangement involving three replications. Soil physical and chemical properties, crop phenology, growth parameters, yield components, and yield data were collected. Analysis of variance showed that crop phenology, productive tillers, and straw yield were significantly affected by $\mathrm{KCl}$ and NPS fertilizer rates; however, most of growth parameters, yield components, grain yield, and agronomic efficiency were influenced by the interaction effects of KCl and NPS fertilizers. Combined application of $50 \mathrm{~kg} \cdot \mathrm{ha}^{-1} \mathrm{KCl}$ and $150 \mathrm{~kg} \cdot \mathrm{ha}^{-1} \mathrm{NPS}$ resulted in highest growth, yield component, grain yield, agronomic efficiency, and economic return, whereas the lowest measured values were recorded from unfertilized plots. The maximum grain yield $\left(4.34 \mathrm{t} \mathrm{ha}^{-1}\right)$ that was recorded from $50 \mathrm{~kg} \cdot \mathrm{ha}^{-1} \mathrm{KCl}$ and $150 \mathrm{~kg} \cdot \mathrm{ha}^{-1} \mathrm{NPS}$ was 8.86 -fold higher than the minimum yield $(0.44 \mathrm{t}$ $\mathrm{ha}^{-1}$ ) from the control. It is concluded that $50 \mathrm{~kg} \cdot \mathrm{ha}^{-1} \mathrm{KCl}$ and $150 \mathrm{~kg} \cdot \mathrm{ha}^{-1} \mathrm{NPS}$ are suggested for better agronomic and economic performance of wheat. As NPS was tested in the blended form, the individual and interaction effects of nutrients under investigation are suggested as future research areas. Additional investigation over season and location is also recommended.
\end{abstract}

\section{Introduction}

Ethiopia is the second-largest wheat producer in sub-Saharan Africa, after South Africa [1]. Wheat in Ethiopia has become one of the most important cereal crops ranking $4^{\text {th }}$ in total grain production $\left(4.53 * 10^{6} \mathrm{t}\right)$ and area $\left(1.69 * 10^{6} \mathrm{ha}\right)$ next to teff (Eragrostis teff), maize (Zea mays L.), and sorghum (Sorghum bicolor L. Moench) [2]. The average productivity of wheat at the national level, South Nation, Nationalities, and People Regional State (SNNPRS), and Wolaita zone of SNNPRS is $2.67,2.58$, and $1.45 \mathrm{ton} \cdot \mathrm{ha}^{-1}$, respectively [2]. However, potential yield of wheat goes beyond $5 \mathrm{t} \cdot \mathrm{ha}^{-1}$ that rises questionable yield gap between farmers' and attainable yield of the crop [3-5].

The depletion of soil nutrients, low level of chemical fertilizer usage, and poor management practices are among the major constraints for improving wheat yield in Ethiopia $[6,7]$. Based on the national soil database of Ethiopia [8], continuous wheat cultivation has resulted in the depletion of macronutrients and also the micronutrients such as zinc $(\mathrm{Zn})$, boron $(\mathrm{B})$, and copper $(\mathrm{Cu})$ in the major crop-producing areas of the country. The survey result on soils of SNNPRS showed the limitation of nitrogen $(\mathrm{N})$, phosphorous $(\mathrm{P})$, potassium $(\mathrm{K})$, sulfur $(\mathrm{S}), \mathrm{Zn}, \mathrm{B}$, and iron $(\mathrm{Fe})[8]$. All these recall the need to address the problem through balanced fertilization.

Balanced fertilization not only guarantees optimal crop production, better food quality, and benefits for the growers but also provides the best solution for minimizing the risk of nutrient losses to the environment [9]. Fertilization, particularly of the macronutrients such as $\mathrm{N}, \mathrm{P}, \mathrm{K}$, and $\mathrm{S}$, is a 
major input in wheat production affecting yield and quality $[10,11]$. Various research studies so far conducted in Ethiopia showed different amounts of fertilizer rates for wheat cultivation. For instance, the study made by Esayas [9] indicated that $100 \mathrm{~kg}$ of NPS (19-38-0-7S) and $125 \mathrm{~kg} \cdot \mathrm{ha}^{-1}$ urea (46-0-0) top-dressed resulted in maximum yield $\left(2.91 \mathrm{t} \cdot \mathrm{ha}^{-1}\right)$ of wheat in the Adaa district of Eastern Shewa Zone, Ethiopia. Additionally, research conducted in the Dawro zone of southern Ethiopia showed that application of $69 \mathrm{~kg} \cdot \mathrm{ha}^{-1} \mathrm{~N}$ and $30 \mathrm{~kg} \mathrm{ha}{ }^{-1} \mathrm{P}$ resulted in the highest grain yield of bread wheat $\left(4.02 \mathrm{t} \cdot \mathrm{ha}^{-1}\right)$ [12]. Furthermore, in the Hawzen district of Tigray Region, Northern Ethiopia, application of $\mathrm{P}$ with $\mathrm{N}$ at a rate of $46 \mathrm{~kg} \cdot \mathrm{ha}^{-1}$ gave grain yield $\left(3.8 \mathrm{t} \cdot \mathrm{ha}^{-1}\right)$ [13]. The study in Wolaita area by Laekemariam et al. $[14,15]$ demonstrated that $46 \%$ of essential nutrients sourced from soil (i.e., N, P, K, S, B, and $\mathrm{Cu}$ ) were identified as principal growth-limiting factors. Meanwhile, research findings have shown that the $\mathrm{K}$ limitation in Wolaita area was potentially related to magnesium-induced deficiency $[15,16]$. However, application of mineral $\mathrm{K}$ has not been practiced in this area. Yet, to our knowledge, in Wolaita area, the performances of wheat under the application of $\mathrm{N}, \mathrm{P}, \mathrm{K}$, and $\mathrm{S}$ fertilizers have not been studied. Thus, it is hypothesized that wheat grown under multinutrient-deficient soils of Wolaita can respond and result in better yield through the application of N, P, K, and S. Therefore, this study was initiated with the following objectives: (i) to investigate the growth and yield response of bread wheat to $\mathrm{K}$ and blended NPS fertilizer rates on the study area, (ii) to examine the nutrient use efficiency of wheat, and (iii) to evaluate the economic feasibility of the fertilizers for bread wheat production.

\section{Materials and Methods}

2.1. Description of the Study Area. This experiment was conducted at Kokate-Marachere $\left(06^{\circ} 53^{\prime} 34.8^{\prime \prime} \mathrm{N}\right.$ latitude and $37^{\circ} 48^{\prime} 42,4^{\prime \prime}$ E longitude), Sodo Zuria district, Wolaita Zone, Southern Ethiopia. The mean altitude of the area is 2000 meters above sea level (m.a.s.l). The experimental area has a bimodal rainfall with the lowest and highest rainfall of $1000 \mathrm{~mm}$ and $1500 \mathrm{~mm}$, respectively. The ten-year average annual rainfall was $1250 \mathrm{~mm}$, and the rainy season extends from March to September. The mean annual minimum and maximum temperature is 19.5 and $24.2^{\circ} \mathrm{C}$, respectively [17].

Major annual crops growing in the area include haricot bean (Phaseolus vulgaris L.), wheat (Triticum aestivum L.), maize (Zea mays L), barley (Hordem vulgare), sweet potato (Ipomoea batatas), and teff (Eragrostis teff). The vegetation is dominated by eucalyptus trees (Eucalyptus camaldulensis), as homestead and farm forest. The area is characterized by nitisol and gentle slope (4-8\%) where farmers practiced livestock-crop production farming system.

\subsection{Experimental Nutrient Sources and Materials.} Potassium and NPS fertilizers were used for the study. The source of $\mathrm{K}$ was $\mathrm{KCl}$ (0-0-60), while the source of NPS was blended NPS (18\% N-38\% $\left.\mathrm{P}_{2} \mathrm{O}_{5}-7 \% \mathrm{~S}\right)$. Bread wheat variety
Danda'a which was developed and released by Kulumsa Agricultural Research Centre in 2010 was used as the test crop. It is a high-yielding white-seeded variety adapted to a wide range of altitudes of 2000 to 2600 m.a.s.l (mid to highland areas) and rainfall of greater than $600 \mathrm{~mm}$. Days to heading, days to physiological maturity, and plant height of the variety are $56-80,110-145$, and $90-113 \mathrm{~cm}$, respectively. The variety is able to produce a grain yield of $2500-5000 \mathrm{~kg} \cdot \mathrm{ha}^{-1}$ at farmers' fields and is also resistant to leaf rust [18].

2.3. Treatments and the Experimental Design. The treatment consisted of five rates of blended NPS $(0,50,100,150$, and $\left.200 \mathrm{~kg} \cdot \mathrm{ha}^{-1}\right)$ and four rates of $\mathrm{K}\left(0,25,50\right.$, and $\left.75 \mathrm{~kg} \cdot \mathrm{ha}^{-1}\right)$. The treatments were combined in factorial arrangement and laid out in randomized complete block design (RCBD) with three replications. The total and net plot size was $4 \mathrm{~m}^{2}$ $(2 \mathrm{~m} \times 2 \mathrm{~m})$ and $3.2 \mathrm{~m}^{2}(1.6 \mathrm{~m} \times 2 \mathrm{~m})$, respectively. The spacing between blocks and plots was 1.0 and $0.5 \mathrm{~m}$, respectively.

2.4. Experimental Procedures and Management. The land was cleared and ploughed thrice with oxen, while disking and harrowing were done manually. After leveling, the layout was prepared against soil fertility grading and slope. Sowing was done at a seed rate of $125 \mathrm{~kg} \cdot \mathrm{ha}^{-1}$ during the mid of July in 2016 with a recommended spacing of $25 \mathrm{~cm}$ between rows. The total number of rows per plot was eight and harvesting rows was six, while two rows at the border of each side of the plot were ignored. The NPS and $\mathrm{KCl}$ fertilizers were applied as per the proposed treatment levels at sowing time by drilling, while urea (46-0-0) fertilizer at a rate of $100 \mathrm{~kg} \cdot \mathrm{ha}^{-1}$ was applied with top dress during the tillering stage for all plots. All other necessary agronomic management practices were carried out properly throughout the cropping season.

\subsection{Data Collection and Measurements}

2.5.1. Soil Data. Before sowing, ten subsamples to form one $\mathrm{kg}$ of the composite sample from the experimental site were collected in a zigzag pattern at the depth of $0-20 \mathrm{~cm}$ to represent the plough layer. The samples were air-dried, ground using a pestle and a mortar, and allowed to pass through a $2 \mathrm{~mm}$ and $0.5 \mathrm{~mm}$ sieve. The sample was analyzed for soil particle size distribution, soil $\mathrm{pH}$, organic carbon (OC), total $\mathrm{N}$, available $\mathrm{P}$, available $\mathrm{K}$, available $\mathrm{S}$, and cation exchange capacity (CEC) using standard laboratory procedures. Soil particle size was analyzed by the Bouyoucos hydrometer method [19]. Soil $\mathrm{pH}$ was measured in water at a soil-to-water ratio of $1: 2.5$ [20]. Organic carbon content was determined by the volumetric method [21]. Total $\mathrm{N}$ was analyzed by the micro-Kjeldahl digestion method with sulfuric acid [22]. Available P was determined by Olsen's method using a spectrophotometer [23]. Exchangeable $\mathrm{K}$ was determined with the ammonium acetate extract method using flame photometry [24]. Available S was measured 
using the turbidity method [25]. Cation exchange capacity (CEC) was measured after saturating the soil with $1 \mathrm{~N}$ ammonium acetate $\left(\mathrm{NH}_{4} \mathrm{OAc}\right)$ and displacing it with $1 \mathrm{~N}$ $\mathrm{NaOAc}[26]$.

2.5.2. Crop Data Collection and Procedures. Data on crop phenology such as days to $50 \%$ heading and days to physiological maturity were collected. Wheat crop growth-indicating parameters such as plant height, leaf area, and yield and yield components such as the number of tillers per plant, number of productive tillers per plant, number of grains per spike, and thousand-grain weight $(\mathrm{g})$ were collected. In addition, straw yield $\left(\mathrm{t} \cdot \mathrm{ha}^{-1}\right)$, grain yield $\left(\mathrm{t} \cdot \mathrm{ha}^{-1}\right)$, above-ground dry biomass $\left(\mathrm{t} \cdot \mathrm{ha}^{-1}\right)$, and harvest index (\%) were recorded. Furthermore, agronomic efficiency (AE) $\left(\mathrm{kg}^{\mathrm{kg}}{ }^{-1}\right)$ was computed. The details of each parameter are given as follows.

Days to $50 \%$ heading were determined by counting the number of days taken from the date of sowing to $50 \%$ heading. Days to physiological maturity were recorded when $90 \%$ of all plants per plot lost chlorophyll and turned yellow. This was determined on visual basis. Plant height was determined from the base to the tip of the spike (awns excluded) of 10 randomly pretagged plants from the net plot area at physiological maturity. Leaf area of flag leaves $(\mathrm{cm})$ was measured from 5 randomly pretagged plants from the net plot areas. It was calculated as length $\times$ maximum width $\times 0.68$. Number of tillers per plant was determined from 10 randomly pretagged plants per plot at heading. Number of productive tillers was determined at maturity by counting all spikes producing seeds of 10 plants/plot. Number of grains per spike was the mean number of grains per spike computed as an average of 10 randomly taken spikes from the central unit area, threshed, and grains were counted using an electronic seed counter.

Above-ground dry biomass $\left(\mathrm{t} \cdot \mathrm{ha}^{-1}\right)$ was measured from plants harvested from the net plot area after sun drying for 4 days and converted into tons per hectare. Straw yield (t.ha ${ }^{-1}$ ) was obtained as the difference of the total above-ground plant biomass and grain yield of plants in the net plot area and converted into ton per hectare. Thousand-grain weight (g) was determined based on the weight of 1000 grains sampled from the grain yield of each treatment by using an electronic seed counter and weighed with an electronic balance. Grain yield (ton $\cdot \mathrm{ha}^{-1}$ ) was taken by harvesting and threshing the seed yield from the net plot area, adjusted to $12.5 \%$ moisture content and expressed in ton per hectare using the following formula [27]:

$$
\text { grain yield = actual yield } \times \frac{100-\mathrm{M}}{100-\mathrm{D}},
$$

where $M$ is the measured moisture content in grain and $D$ is the designated moisture content.

Harvest index (\%): harvest index (HI) was computed as the ratio of dry seed yield and above-ground dry biomass yield using the following formula [28]:

$$
\mathrm{HI}(\%)=\frac{\text { grain yield }}{\text { biomass }} \times 100 .
$$

Agronomic efficiency (AE) $\left(\mathrm{kg} \cdot \mathrm{kg}^{-1}\right)$ refers to the economic production obtained per unit of nutrient applied, and it was estimated using the formula indicated in Baligar et al. [29]:

$$
\mathrm{AE}(\mathrm{kg} / \mathrm{kg})=\frac{\mathrm{Gf}-\mathrm{Gu}}{\text { quantity of nutrient applied }(\mathrm{kg})},
$$

where $\mathrm{Gf}=$ grain yield of the fertilized plants $(\mathrm{kg})$ and $\mathrm{Gu}=$ grain yield of the unfertilized plants $(\mathrm{kg})$.

2.6. Statistical Analysis. Data were subjected to analysis of variance (ANOVA) following the standard procedure using the SAS GLM procedure [30]. Mean separation was done using least significant difference (LSD) at $5 \%$ of the probability level whenever significant differences among treatment means were detected.

2.7. Partial Budget Analysis. Economic analysis was performed to investigate the economic feasibility of the treatments based on the procedure given by CIMMYT [31]. Partial budget and marginal analyses were used. The average grain yield was adjusted to $10 \%$ downwards to reflect the difference between the experimental yield and the yield of farmers expected from the same treatment. The average fertilizer prices of NPS (15.52 birr. $\mathrm{kg}^{-1}$ ) and potassium (12.17 birr. $\left.\mathrm{kg}^{-1}\right)$ during the study period were used for analysis. The average open market price was $10 \mathrm{birr} \cdot \mathrm{kg}^{-1}$ of wheat grain. Net revenue $(\mathrm{NR})=$ total revenue $(\mathrm{TR})-$ total variable cost (TVC), and the final line of the partial budget is the net benefits. It was calculated by subtracting the total costs that vary from the gross field benefits for each treatment. Marginal rate of return $(\mathrm{MRR} \%)=\Delta \mathrm{NR} /$ $\Delta \mathrm{TVC} * 100$, which is the marginal net benefit (i.e., the change in net benefits) divided by the marginal cost (i.e., the change in costs). A treatment was considered worth to farmers when its minimum acceptable rate of return (MAR) is $100 \%$, which is suggested to be realistic. This enables to make farmer recommendations from marginal analysis.

\section{Results and Discussion}

3.1. Physicochemical Properties of the Experimental Site. The soil analysis result of selected physical and chemical properties of the experimental site is presented in Table 1. The experimental soil was clay in texture. Soil $\mathrm{pH}$ was 5.86 and was rated as moderately acidic soil (5.6-6.5) [32]. The OC content was $2.2 \%$ which was low (2-4\%) [33]. The site had a TN content of $0.16 \%$ which was categorized under the low level $(0.1-0.2 \%)$ [33]. The available $\mathrm{P}$ content was $12.39 \mathrm{mg} \cdot \mathrm{kg}^{-1}$ soil which was rated under medium [34]. Available K was $0.96 \mathrm{cmol} \cdot \mathrm{kg}^{-1}$ which was under the high category $\left(0.6-1.2 \mathrm{cmol}(+) \mathrm{kg}^{-1}\right)$ [24]. However, in the study area, evidence of $\mathrm{Mg}$-induced $\mathrm{K}$ deficiency under soils having higher exchangeable $\mathrm{K}$ was reported by Laekemariam et al. $[15,16]$.

The available $S$ content was $5.03 \mathrm{mg} \cdot \mathrm{kg}^{-1}$ and rated under the low category $\left(\leq 10 \mathrm{mg} \cdot \mathrm{kg}^{-1}\right)$ [23]. The CEC content was $25.1 \mathrm{cmol}(+) \cdot \mathrm{kg}^{-1}$ of soil which was rated under the medium $\left(25-40 \mathrm{cmol} \cdot \mathrm{kg}^{-1}\right)$ category [30]. Overall, the inadequate amount of OC, TN, and S (Table 1) and potential of $\mathrm{Mg}$ - 
TABLE 1: Selected soil physicochemical properties of the experimental site.

\begin{tabular}{lccc}
\hline Parameter & Value & Rating & Reference \\
\hline Physical & & & \\
Soil particle size distribution & & & \\
$\quad$ Sand & 23.75 & & Hazelton and Murphy [32] \\
$\quad$ Silt & 30.07 & \\
$\quad$ Clay & 46.18 & & \\
Texture class & Clay & & \\
Chemical & & & Hazelton and Murphy [32] \\
pH $(1: 2.5$ soil-to-water ratio) & 5.86 & Landon [33] \\
Organic carbon & 2.2 & Low \\
Total nitrogen $(\%)$ & 0.16 & Low & Landon [33] \\
CEC $\left(\mathrm{cmol}(+) \cdot \mathrm{kg}^{-1}\right)$ & 25.11 & Medium & Landon [33] \\
Available phosphorous $\left(\mathrm{mg}^{-1} \mathrm{~kg}^{-1}\right)$ & 12.39 & Medium & Cottenie [34] \\
Available K $\left(\mathrm{cmol}(+) \cdot \mathrm{kg}^{-1}\right)$ & 0.96 & High & FAO [24] \\
Available sulfur $\left(\mathrm{mg}^{-1}\right)$ & 5.03 & Low & Allen and Pilbeam [25] \\
\hline
\end{tabular}

induced $\mathrm{K}$ deficiency $[15,16]$ were ascribed due to inadequate soil fertility management practices.

\subsection{Crop Phenology}

3.2.1. Days to $50 \%$ Heading. Days to $50 \%$ heading were significantly $(P<0.05)$ affected by NPS and K fertilizers, but not their interaction (Tables 2 and 3). Increasing levels of the NPS fertilizer shortened days to $50 \%$ heading from 74.6 days (150 kg.ha ${ }^{-1}$ NPS) to 59.5 days (unfertilized plot). This might be attributed to the promotion of early vegetative growth and development as a result of availability of $\mathrm{N}, \mathrm{P}$, and $\mathrm{S}$ nutrients for uptake that in turn enhanced days to heading. The findings on $\mathrm{N}$ and $\mathrm{S}$ [35] and $\mathrm{P}$ [36] showed that adequate supply of $\mathrm{N}, \mathrm{P}$, and $\mathrm{S}$ enhances many aspects of plant physiology such as photosynthesis.

Days to $50 \%$ heading varied from 62.5 to 68.5 where the minimum and maximum days were recorded from $50 \mathrm{~kg} \cdot \mathrm{ha}^{-1} \mathrm{KCl}$ and unfertilized plots, respectively (Table 2). However, rates between 25 and $75 \mathrm{~kg} \cdot \mathrm{ha}^{-1} \mathrm{KCl}$ had a similar effect on days to $50 \%$ heading. It was clear from the data that days to $50 \%$ heading on wheat were shortened with increasing levels of $\mathrm{KCl}$ (Table 2). The shortened days to flowering due to $\mathrm{KCl}$, averaged over NPS rate, probably ascribed the beneficial effects of K nutrition to enhance early canopy growth and heading. In agreement with this result, the role of $\mathrm{K}$ in plant physiological processes and stimulation of early growth was reported by Marschner and Lakudzala [37, 38]. Liebersbach et al. [39] also reported that K plays an important role in many physiological processes such as photosynthesis, assimilate transport, and enzyme activation. Such roles of K may enhance plants' growth and make them come early for changing of their phenology. The response of wheat plants to K application under high soil exchangeable $\mathrm{K}$ (Table 1) could reflect the presence of $\mathrm{Mg}$-induced $\mathrm{K}$ deficiency $[15,16,40]$.

3.2.2. Physiological Maturity. Data regarding days to physiological maturity on wheat showed that blended NPS fertilizer application significantly affected $(P<0.05)$ days to reach physiological maturity. However, $\mathrm{KCl}$ fertilizer and its
TABLE 2: Days to $50 \%$ heading and physiological maturity of wheat as affected by NPS and $\mathrm{K}$ fertilizer rates.

\begin{tabular}{lcc}
\hline Fertilizer $\left(\mathrm{kg} \cdot \mathrm{ha}^{-1}\right)$ & $\begin{array}{c}\text { Days to } \begin{array}{c}50 \% \text { heading } \\
\text { Days }\end{array} \\
\text { NPS }\end{array}$ & $\begin{array}{c}\text { Physiological maturity } \\
\text { Days }\end{array}$ \\
0 & $74.6^{\mathrm{a}}$ & $134.25^{\mathrm{a}}$ \\
50 & $65.0^{\mathrm{b}}$ & $133.75^{\mathrm{a}}$ \\
100 & $60.5^{\mathrm{c}}$ & $129.58^{\mathrm{b}}$ \\
150 & $59.5^{\mathrm{c}}$ & $113.42^{\mathrm{d}}$ \\
200 & $63.7^{\mathrm{b}}$ & $117.58^{\mathrm{c}}$ \\
LSD (0.05) & 2.22 & 2.74 \\
\hline KCl & & \\
0 & $68.5^{\mathrm{a}}$ & 126.3 \\
25 & $64.2^{\mathrm{b}}$ & 126.6 \\
50 & $62.5^{\mathrm{b}}$ & 125.1 \\
75 & $63.4^{\mathrm{b}}$ & 124.9 \\
LSD (0.05) & 1.98 & $\mathrm{NS}$ \\
\hline CV (\%) & 4.15 & 2.64 \\
\hline
\end{tabular}

LSD (0.05): least significant difference at the $5 \%$ level; CV: coefficient of variation; NS: nonsignificant. Means in the column followed by the same letters are not significantly different at the $5 \%$ level of significance.

TABLE 3: Mean squares of ANOVA for days to heading, days to physiological maturity, leaf area, and plant height of wheat.

\begin{tabular}{lccccc}
\hline $\begin{array}{l}\text { Source } \\
\text { variance }\end{array}$ & DF & $\begin{array}{c}\text { DH } \\
(\text { days })\end{array}$ & $\begin{array}{c}\text { LA } \\
\left(\mathrm{cm}^{2}\right)\end{array}$ & $\begin{array}{c}\text { DPM } \\
(\text { days })\end{array}$ & $\begin{array}{c}\text { PH } \\
(\mathrm{cm})\end{array}$ \\
\hline REP & 2 & 3.217 & 25.235 & 16.22 & 5.417 \\
NPS & 3 & $433.4^{*}$ & $134.3^{*}$ & $1109.3^{*}$ & $63.3^{*}$ \\
K & 4 & $105.8^{*}$ & $124.2^{*}$ & $10.7^{\mathrm{NS}}$ & $839.3^{*}$ \\
NPS $* \mathrm{~K}$ & 12 & $4.2^{\mathrm{NS}}$ & $20.4^{*}$ & $7.3^{\mathrm{NS}}$ & $5.3^{*}$ \\
Error & 38 & 7.199 & 7.035 & 11.0 & 2.5 \\
\hline
\end{tabular}

NS and $*$ : nonsignificant and significant at $5 \%$. DF: degree of freedom; DH: days to $50 \%$ heading; DPM: days to $90 \%$ physiological maturity; LA: leaf area; $\mathrm{PH}$ : plant height.

interaction with NPS did not influence days to maturity (Table 3). Days to maturity were decreased with increasing rates of the NPS fertilizer. Maturity time varied from 113.42 to 134.25 days where the shortest and longest days were recorded from $150 \mathrm{~kg} \cdot \mathrm{ha}^{-1}$ NPS and unfertilized plots, respectively (Table 2). The early maturity of wheat at higher 
NPS doses might be due to the combined effects of N, P, and $S$ which might have hastened the physiological maturity of the plant. Particularly, $\mathrm{P}$ has a prominent role in reducing days to physiological maturity by controlling some key enzymes involved in hastening crop maturity [37]. Amanullah et al. [41] also indicated early phonological development on maize plants with NPK fertilizer application. Increasing $\mathrm{N}$ supply enhanced growth and consequently increased the demand and absorption of other nutrients (e.g., $\mathrm{P}$ and S) [42]. The dominant role of $\mathrm{N}$ in promoting crop vegetative growth and the positive interaction of $\mathrm{N}$ at increased supply with $\mathrm{P}$ and S [42] might be the reason for the delay in days to $50 \%$ heading and physiological maturity beyond $150 \mathrm{~kg} / \mathrm{ha}$ NPS.

\subsection{Crop Growth}

3.3.1. Plant Height $(\mathrm{cm})$. Plant height revealed significant $(P<0.05)$ differences among rates of NPS and K and their interaction (Tables 3-5). Maximum plant height $(115 \mathrm{~cm})$ was attained from the combined effect of 150 and $50 \mathrm{~kg} \cdot \mathrm{ha}^{-1}$ of NPS and $\mathrm{KCl}$, respectively, whereas the minimum plant height $(90 \mathrm{~cm})$ from the unfertilized plot followed by $0 \mathrm{~kg} \cdot \mathrm{ha}^{-1}$ NPS with $25 \mathrm{~kg} \cdot \mathrm{ha}^{-1}$ (Table 4). Plant height attained from combined effect of 150 and $50 \mathrm{~kg} \cdot \mathrm{ha}^{-1}$ of NPS and $\mathrm{KCl}$, respectively, was $25 \mathrm{~cm}$ higher than plants from the unfertilized plot. However, plant height of wheat under the combined effect of $50 \mathrm{~kg} \cdot \mathrm{ha}^{-1}$ of NPS with $0 \mathrm{~kg} \cdot \mathrm{ha}^{-1}$ of $\mathrm{KCl}$, $0 \mathrm{~kg} \cdot \mathrm{ha}^{-1}$ of NPS with $50 \mathrm{~kg} \cdot \mathrm{ha}^{-1}$ of $\mathrm{KCl}$, and $0 \mathrm{~kg} \cdot \mathrm{ha}^{-1}$ of NPS with $75 \mathrm{~kg} \cdot \mathrm{ha}^{-1}$ of $\mathrm{KCl}$ was statistically similar. Likewise, statistically, the same effects were observed from the combination of other treatments (Table 4). Furthermore, it was noted that a successive increase of NPS and $\mathrm{KCl}$ fertilizers attributed to the gradual increase in the plant height of wheat (Table 4). This could indicate the synergetic effects of NPS and K nutrients in increasing growth which in turn gradually increased the height of wheat plants. These results are in agreement with Ayub et al. [42] and Maqsood et al. [43] who reported that the plant height increased linearly with each successive increase in NPK. Besides, fertilization studies on $\mathrm{N}[12,44]$ and $\mathrm{S}$ [45] exhibited considerable increase in the plant height of wheat in response to each increment of nutrients.

3.3.2. Leaf Area. Leaf area was significantly $(P<0.05)$ influenced by the interaction effects of blended NPS and $\mathrm{KCl}$ application rates (Tables 3-5). It was generally observed that leaf area was found to decline with the reduced rates of NPS and K fertilizers (Table 4). Maximum leaf area $\left(25.27 \mathrm{~cm}^{2}\right)$ was attained at the rate of $150 \mathrm{~kg} \cdot \mathrm{ha}^{-1} \mathrm{NPS}$ and $50 \mathrm{~kg} \cdot \mathrm{ha}^{-1} \mathrm{KCl}$ while the minimum leaf area $\left(4.39 \mathrm{~cm}^{2}\right)$ from treatment where no fertilizer was applied. Leaf area was increased successively as rates of NPS and $\mathrm{KCl}$ increased from 0 to $150 \mathrm{~kg} \cdot \mathrm{ha}^{-1}$ and 0 to $50 \mathrm{~kg} \cdot \mathrm{ha}^{-1}$, respectively (Table 4). This suggests the beneficial effects of $\mathrm{N}$, $\mathrm{P}, \mathrm{K}$, and $\mathrm{S}$ nutrients towards increment of leaf size of wheat plants. Different scholars also explained the positive role of $\mathrm{N}, \mathrm{P}, \mathrm{K}$, and $\mathrm{S}$ for improving crop leaf area. For instance,
Järvan et al. [45] and Ara et al. [46] reported that $N$ enhanced leaf area and interception of photosynthetically active radiation. Jiang et al. [47] indicated that the maximum leaf area was due to increased $\mathrm{P}$ applications. Moreover, Tisdale et al. [48] also described that K application enhanced the photosynthetic capacity and productive life of flag leaves. Furthermore, the role of $S$ in increasing the leaf area was reported [49]. Therefore, the application of $\mathrm{N}, \mathrm{P}, \mathrm{K}$, and $\mathrm{S}$ alone or in combination could improve the growth and development of wheat and consequently contribute to the higher leaf area of wheat. Yet, successive increase of K and NPS fertilizers from 50 to $75 \mathrm{~kg} / \mathrm{ha}$ and 150 to $200 \mathrm{~kg} / \mathrm{ha}$, respectively, reduced the performance of most growth parameters likely implying that the nutrients had reached the saturation level, and beyond that, their antagonistic effects started to appear.

\subsection{Yield and Yield Components}

3.4.1. Total Number of Tillers per Plant. The total number of tillers per plant revealed significant $(P<0.0 .5)$ differences among main and interaction effects of NPS and $\mathrm{KCl}$ fertilizers (Tables 5 and 6). Application of fertilizers at $150 \mathrm{~kg} \cdot \mathrm{ha}^{-1} \mathrm{NPS}$ and $50 \mathrm{~kg} \cdot \mathrm{ha}^{-1} \mathrm{KCl}$ resulted in the highest number of total tillers per plant (6.6), and the minimum number of total tillers per plant (1.33) was observed from unfertilized plots (Table 7). The total number of tillers from the combined effect of 150 and $50 \mathrm{~kg} \cdot \mathrm{ha}^{-1}$ of NPS and $\mathrm{KCl}$, respectively was 5 -fold higher than that of the unfertilized plot. The number of tillers per plant has a vital position in controlling yield of wheat. It is clear that the more the number of tillers is, the better will be the stand of the crop, which ultimately increases the yield. This result agrees with Malghani et al. [50] and Laghari et al. [51] who reported that a progressive increase in NPK levels to optimum levels enhanced the number of tillers per plant. Moreover, Liakas et al. [52] indicated that the application of $\mathrm{P}$ and $\mathrm{K}$ favored tillering of wheat. Therefore, the combined effects of NPS and $\mathrm{K}$ nutrients might have positive effects on the tiller formation of wheat.

3.4.2. Productive Tillers per Plant. The analysis of variance showed that NPS and KCl fertilizers significantly $(P<0.05)$ affected productive tillers per plant, while their interaction effect was nonsignificant (Table 7). It showed an increasing trend with the increasing level of NPS (Table 8). Productive tillers per plant varied from 4.56 to 1.9 which were recorded from $150 \mathrm{~kg} \cdot \mathrm{ha}^{-1}$ NPS and unfertilized plot, respectively (Table 8). However, tillers at 100 and $200 \mathrm{~kg} \cdot \mathrm{ha}^{-1}$ of NPS were statistically at par. In general, application of NPS at different rates had a direct effect on the tiller number per plant in the study field. This result is in agreement with that of Laghari et al. [51] who observed that increasing $\mathrm{N}$ application increased the number of productive tillers per unit area. In addition, fertilization studies on $\mathrm{N}$ and $\mathrm{P}[12,53,54]$ exhibited a considerable increase in productive tillers per plant of wheat in response to each increment of nutrients. 
TABLE 4: Plant height $(\mathrm{cm})$ and leaf area $\left(\mathrm{cm}^{2}\right)$ of wheat as affected by the interaction effect of NPS and K fertilizer rates at Sodo Zuria, Wolaita Zone, Southern Ethiopia, during 2016.

\begin{tabular}{|c|c|c|c|c|}
\hline \multirow{2}{*}{$\begin{array}{l}\text { Fertilizer rates }\left(\mathrm{kg} \cdot \mathrm{ha}^{-1}\right) \\
\text { NPS }\end{array}$} & \multicolumn{4}{|c|}{$\mathrm{KCl}\left(\mathrm{kg} \cdot \mathrm{ha}^{-1}\right)$} \\
\hline & 0 & 25 & 50 & 75 \\
\hline \multicolumn{5}{|l|}{$\mathrm{PH}$} \\
\hline 0 & $90^{\mathrm{i}}$ & $90.67^{\mathrm{i}}$ & $93.67^{\mathrm{h}}$ & $91.67^{\mathrm{hi}}$ \\
\hline 50 & $94^{\mathrm{h}}$ & $96.67^{\mathrm{g}}$ & $98^{\mathrm{g}}$ & $97.33^{\mathrm{g}}$ \\
\hline 100 & $101^{\mathrm{f}}$ & $104^{\mathrm{e}}$ & $109.3^{\mathrm{bcd}}$ & $104^{\mathrm{e}}$ \\
\hline 150 & $109.67^{b c}$ & $109.67^{\mathrm{bc}}$ & $115^{\mathrm{a}}$ & $110.33^{\mathrm{bc}}$ \\
\hline 200 & $109.3^{\mathrm{bcd}}$ & $108.3^{\mathrm{cd}}$ & $111.67^{\mathrm{b}}$ & $107^{\mathrm{d}}$ \\
\hline LSD (0.05) & \multicolumn{4}{|c|}{2.64} \\
\hline $\mathrm{CV}(\%)$ & \multicolumn{4}{|c|}{1.56} \\
\hline \multicolumn{5}{|l|}{ LA } \\
\hline 0 & $4.39^{\mathrm{h}}$ & $6.47^{\mathrm{gh}}$ & $6.75^{\mathrm{gh}}$ & $7.37^{\mathrm{fgh}}$ \\
\hline 50 & $8.053^{\text {efgh }}$ & $8.66^{\text {defgh }}$ & $11.96^{\mathrm{cde}}$ & $9.85^{\text {defg }}$ \\
\hline 100 & $10.35^{\text {defg }}$ & $12.08^{\text {cde }}$ & $18.01^{\mathrm{b}}$ & $11.48^{\text {cdef }}$ \\
\hline 150 & $10.07^{\mathrm{defg}}$ & $11.67^{\text {cdef }}$ & $25.28^{\mathrm{a}}$ & $12.47^{\mathrm{cd}}$ \\
\hline 200 & $11.15^{\text {cdef }}$ & $11.3^{\text {cdef }}$ & $14.83^{\mathrm{bc}}$ & $11.94^{\text {cde }}$ \\
\hline LSD (0.05) & \multicolumn{4}{|c|}{4.38} \\
\hline CV (\%) & \multicolumn{4}{|c|}{23.67} \\
\hline
\end{tabular}

LSD (0.05): least significant difference at the $5 \%$ level; CV: coefficient of variation; means in the column followed by the same letters are not significantly different at the $5 \%$ level; $\mathrm{PH}$ : plant height; LA: leaf area.

Productive tillers per plant due to $\mathrm{K}$ application varied from 3.64 to 3.01 where they were recorded under $50 \mathrm{~kg} \cdot \mathrm{ha}^{-1} \cdot \mathrm{KCl}$ and unfertilized plots, respectively (Table 8). It was clear from the data that they showed an increasing trend with increasing levels of $\mathrm{K}$ (Table 6). These results agreed with Tahir et al. [53] who indicated an increased productive tiller of wheat due to K application. Additionally, Baque et al. [55] reported maximum effective tillers in wheat plants received from higher levels of $\mathrm{K}$.

3.4.3. Number of Grains per Spike. The number of grains per spike was significantly $(P<0.05)$ influenced by NPS and $\mathrm{KCl}$ and their interaction (Tables 5 and 6). Application of NPS fertilizers at $150 \mathrm{~kg} \cdot \mathrm{ha}^{-1}$ with $\mathrm{KCl}$ at $50 \mathrm{~kg} \cdot \mathrm{ha}^{-1}$ showed the highest number of grains per spike (50.6), while the minimum number of grains per spike (16.33) was recorded from the unfertilized plot (Table 7). Increase in the rate of NPS and $\mathrm{KCl}$ increased from 0 to $150 \mathrm{~kg} \cdot \mathrm{ha}^{-1}$ and 0 to $50 \mathrm{~kg} \cdot \mathrm{ha}^{-1}$, and the number of grains per spike was increased by 83 and $39 \%$, respectively (Table 7). Similar to tiller production, the number of grains per spike has also shown an observable relationship with the fertilizers used in the treatment fields. Corroborating to the present study, the role of $\mathrm{N}$ [51], P [12], and $\mathrm{K}$ in simulating the growth and development and thereby leading to a higher number of grains per spike on wheat was reported by Baque et al. [55]. In addition, Malghani et al. [50] also reported that an increasing rate of NPK increased the number of grains per spike.

3.4.4. Thousand-Grain Weight. The data regarding thousand-grain weights are presented in Tables 5 and 6 . Thousand-grain weights revealed significant $(P<0.05)$ differences under varying levels of NPS and $\mathrm{KCl}$ and their interaction. Application of $150 \mathrm{~kg} \mathrm{ha}^{-1}$ NPS with $\mathrm{KCl}$ at $50 \mathrm{~kg} \cdot \mathrm{ha}^{-1}$ showed the highest grain weight $(56.3 \mathrm{~g})$, while minimum number of grain weight $(27.33 \mathrm{~g})$ was recorded from unfertilized plot (Table 7). Thousand-grain weights were increased by 32 and $18 \%$ when the application of NPS and $\mathrm{KCl}$ increased from 0 to $150 \mathrm{~kg} \cdot \mathrm{ha}^{-1}$ and 0 to $50 \mathrm{~kg} \cdot \mathrm{ha}^{-1}$, respectively (Table 4 ). This result might be due to the synergistic effect of NPS and K nutrients that enhanced the thousand-grain weight of the crop. Previous studies on $\mathrm{N}$ [56], P [57], K [58], and NPKSZn [59] demonstrated that the addition of these nutrients alone or together improved photosynthetic activity, enhanced sink transport to the grain, and resulted in heavier grains. Moreover, the significant effect of $\mathrm{P}$ and $\mathrm{K}$ application on the yield component of wheat was reported [60]. Furthermore, fertilization of $S$ for enhancing the uptake of N, P, and K and the synergistic effect of these elements towards increased productivity were also reported [11].

3.4.5. Above-Ground Biomass. The total above-ground biomass of the crop was significantly $(P<0.05)$ affected by rates of NPS and $\mathrm{KCl}$ and their interaction (Tables 5 and 9). Higher dry biomass yield $\left(9.5 \mathrm{tha}^{-1}\right)$ was obtained from the combination of $150 \mathrm{~kg} \cdot \mathrm{ha}^{-1}$ NPS and $50 \mathrm{~kg} \cdot \mathrm{ha}^{-1} \mathrm{KCl} \mathrm{fol-}$ lowed by $150 \mathrm{~kg} \cdot \mathrm{ha}^{-1} \mathrm{NPS}$ and $75 \mathrm{~kg} \cdot \mathrm{ha}^{-1} \mathrm{KCl}$ (Table 9), while unfertilized plots recorded the lowest biomass $\left(1.13 \mathrm{t} \cdot \mathrm{ha}^{-1}\right)$. Total above-ground biomass showed an increment of 279 and $49 \%$ as the rate of NPS and $\mathrm{KCl}$ application increased from 0 to $150 \mathrm{~kg} \cdot \mathrm{ha}^{-1}$ and 0 to $50 \mathrm{~kg} \cdot \mathrm{ha}^{-1}$, respectively (Table 7). In this study, the above-ground biomass has shown an increasing trend with an increasing amount of fertilizer rates (Table 7). The higher dry biomass at $150 \mathrm{~kg} \cdot \mathrm{ha}^{-1}$ NPS and $50 \mathrm{~kg} \cdot \mathrm{ha}^{-1} \mathrm{KCl}$ could be attributed to the highest plant height, leaf area, number of productive tillers, and number of grains per spike. Similarly, the combined use of NPK resulted in the highest biological yield of wheat [61].

3.4.6. Grain Yield. Grain yield was significantly $(P<0.05)$ influenced due to main and interaction effects of NPS and $\mathrm{KCl}$ fertilizer rates (Tables 5 and 9). The maximum grain yield $\left(4.33 \mathrm{t} \cdot \mathrm{ha}^{-1}\right)$ was recorded from the combined application of $150 \mathrm{~kg} \cdot \mathrm{ha}^{-1} \mathrm{NPS}$ and $50 \mathrm{~kg} \cdot \mathrm{ha}^{-1} \mathrm{KCl}$ followed by $150 \mathrm{~kg} \cdot \mathrm{ha}^{-1}$ NPS and $75 \mathrm{~kg} \cdot \mathrm{ha}^{-1} \mathrm{KCl}\left(3.44 \mathrm{t} \cdot \mathrm{ha}^{-1}\right)$ (Table 7). On the contrary, the least grain yield $\left(0.44 \mathrm{t}_{\mathrm{ha}} \mathrm{h}^{-1}\right)$ was recorded from unfertilized treatments. In general, the yield obtained from $150 \mathrm{~kg} \cdot \mathrm{ha}^{-1} \mathrm{NPS}$ and $50 \mathrm{~kg} \cdot \mathrm{ha}^{-1} \mathrm{KCl}$ was 8.84fold higher than the yield obtained from unfertilized treatments. The grain yield advantages due to NPS and $\mathrm{KCl}$ fertilization could be attributed to synergistic effects of applied nutrients that enhanced the growth and yield of wheat. The result was in agreement with that of Doberman and Fairhurst [11] who reported that the combined effects of $\mathrm{N}, \mathrm{P}, \mathrm{K}$, and $\mathrm{S}$ increased crop productivity. Asghar et al. [62] also concluded that an increase in NPK application resulted in increased grain yield of maize and other cereal crops. Brhane et al. [59] recommended $60 \mathrm{~kg} \mathrm{~K}_{2} \mathrm{O}$ and blended 
TABLE 5: Growth, yield component, yield, and agronomic efficiency of wheat as affected by NPS and K fertilizer rates at Sodo Zuria, Wolaita Zone, Southern Ethiopia, during 2016.

\begin{tabular}{|c|c|c|c|c|c|c|c|c|}
\hline & $\begin{array}{c}\text { PHT } \\
\mathrm{cm}\end{array}$ & $\begin{array}{l}\mathrm{LA} \\
\mathrm{cm}\end{array}$ & $\begin{array}{c}\text { NGPS } \\
\text { No. }\end{array}$ & $\begin{array}{c}\text { TKW } \\
\text { gm }\end{array}$ & $\begin{array}{c}\text { AGBM } \\
\mathrm{t} \mathrm{ha}^{-1}\end{array}$ & $\begin{array}{c}\mathrm{GY} \\
\mathrm{t} \mathrm{ha}^{-1}\end{array}$ & $\begin{array}{l}\text { SY } \\
\mathrm{t} \mathrm{ha}^{-1}\end{array}$ & $\begin{array}{c}\mathrm{AE} \\
\mathrm{kg} \cdot \mathrm{kg}^{-1}\end{array}$ \\
\hline \multicolumn{9}{|l|}{ NPS } \\
\hline 0 & $91.50^{\mathrm{e}}$ & $6.24^{\mathrm{d}}$ & $22.67^{\mathrm{d}}$ & $35.00^{c}$ & $1.983^{\mathrm{e}}$ & $0.806^{\mathrm{e}}$ & $0.78^{\mathrm{d}}$ & $6.5^{\mathrm{d}}$ \\
\hline 50 & $96.50^{\mathrm{d}}$ & $9.63^{c}$ & $31.67^{\mathrm{c}}$ & $42.92^{\mathrm{b}}$ & $3.717^{\mathrm{d}}$ & $1.528^{\mathrm{d}}$ & $2.050^{\mathrm{c}}$ & $12.26^{\mathrm{b}}$ \\
\hline 100 & $104.58^{\mathrm{c}}$ & $12.98 \mathrm{a}^{\mathrm{b}}$ & $37.75^{\mathrm{b}}$ & $45.58^{\mathrm{ab}}$ & $5.900^{c}$ & $2.517^{\mathrm{c}}$ & $3.107^{\mathrm{b}}$ & $15.44^{\mathrm{a}}$ \\
\hline 150 & $111.17^{\mathrm{a}}$ & $14.86^{\mathrm{a}}$ & $41.58^{\mathrm{a}}$ & $46.08^{\mathrm{a}}$ & $7.533^{\mathrm{a}}$ & $3.242^{\mathrm{a}}$ & $4.113^{\mathrm{a}}$ & $14.95^{\mathrm{a}}$ \\
\hline 200 & $109.08^{\mathrm{b}}$ & $12.30^{\mathrm{b}}$ & $36.08^{b}$ & $44.083^{\mathrm{ab}}$ & $6.9333^{\mathrm{b}}$ & $2.832^{\mathrm{b}}$ & $3.859^{\mathrm{a}}$ & $10.13^{c}$ \\
\hline LSD (0.05) & 1.32 & 2.19 & 1.912 & 2.742 & 0.314 & 0.163 & 0.297 & 1.573 \\
\hline \multicolumn{9}{|l|}{$\mathrm{KCl}$} \\
\hline 0 & $100.80^{c}$ & $8.79^{\mathrm{b}}$ & $28.87^{\mathrm{c}}$ & $39.93^{c}$ & $4.187^{\mathrm{d}}$ & $1.645^{\mathrm{d}}$ & $2.545^{\mathrm{b}}$ & $9.94^{\mathrm{c}}$ \\
\hline 25 & $101.87^{b c}$ & $10.04^{\mathrm{b}}$ & $33.47^{\mathrm{b}}$ & $42.67^{\mathrm{b}}$ & $4.580^{c}$ & $1.913^{c}$ & $2.645^{\mathrm{b}}$ & $10.45^{b c}$ \\
\hline 50 & $105.53^{\mathrm{a}}$ & $15.37^{\mathrm{a}}$ & $40.00^{\mathrm{a}}$ & $46.20^{\mathrm{a}}$ & $6.247^{\mathrm{a}}$ & $2.727^{\mathrm{a}}$ & $3.132^{\mathrm{a}}$ & $15.42^{\mathrm{a}}$ \\
\hline 75 & $102.07^{\mathrm{b}}$ & $10.62^{\mathrm{b}}$ & $33.47^{\mathrm{b}}$ & $42.13 b^{c}$ & $5.840^{\mathrm{b}}$ & $2.455^{\mathrm{b}}$ & $2.807^{\mathrm{b}}$ & $11.62^{\mathrm{b}}$ \\
\hline LSD $(0.05)$ & 1.18 & 1.96 & 1.711 & 2.452 & 0.281 & 0.146 & 0.265 & 1.407 \\
\hline
\end{tabular}

LSD: least significant difference at the $5 \%$ level; means in the column followed by the same letters are not significantly different at the $5 \%$ level; PH: plant height; LA: leaf area; TTNPP: total number of tillers per plant; TKW: thousand-grain weights; NGPS: number of grains per spike; AGBM: above-ground biomass; GY: grain yield; SY: straw yield; AE: agronomic efficiency.

TABLE 6: Mean squares of ANOVA for the number of tillers per plant, number of productive tillers per plant, grain per spike, and 1000-grain weight of wheat.

\begin{tabular}{lccccc}
\hline Source variance & DF & TNPP & PT & NGPS & TGW \\
\hline REP & 2 & 1.163 & 0.1132 & 26.6 & 3.217 \\
NPS & 3 & $7.434^{*}$ & $1.1293^{*}$ & $11.808^{*}$ & $629.358^{*}$ \\
K & 4 & $7.827^{*}$ & $0.0825^{\text {NS }}$ & $11.092^{*}$ & $101.11^{*}$ \\
NPS $*$ K & 12 & $0.878^{*}$ & 0.0414 & 5.354 & $38.472^{*}$ \\
Error & 38 & 0.34545 & 11.006 \\
\hline
\end{tabular}

NS and $*$ : nonsignificant and significant at 5\%. NTPP: number of tillers per plant; PNTPP: number of productive tillers per plant; NGPS: number of grains per spike; TGW: 1000-grain weight.

NPKSZ as economically feasible rate for wheat-growing farmers in vertisol of Tigray Region, Ethiopia. Additionally, scholars working on individual nutrients such as $\mathrm{N}[63], \mathrm{P}$ [64], $\mathrm{K}[58]$, and $S[45,65]$ have shown an increase in grain yield of wheat due to applied N, P, K, and S nutrients, respectively. Therefore, the grain yield advantage in the present study reflects the level of N, P, K, and S in the study area and the beneficial effects of blended NPS and K fertilizers in achieving high yields.

3.4.7. Straw Yield. Straw yield of wheat was significantly affected $(P<0.05)$ by the main and interaction effects of NPS and $\mathrm{KCl}$ fertilizer rates (Tables 5 and 9). The highest straw $\left(5.13 \mathrm{t} \cdot \mathrm{ha}^{-1}\right.$ ) yield was recorded from $150 \mathrm{~kg} \cdot \mathrm{ha}^{-1}$ NPS and $50 \mathrm{~kg} \cdot \mathrm{ha}^{-1} \mathrm{KCl}$ which showed an increment of $7 \mathrm{t} \cdot \mathrm{ha}^{-1}$ as compared to the lowest straw yield $\left(0.64 \mathrm{t} \mathrm{ha}^{-1}\right)$ recorded from unfertilized plots (Table 10). Previous studies on N and P [66], P [67], and $S$ [68] reported that the addition of these nutrients could improve the grain and straw yield.

3.4.8. Harvest Index. Analysis of variance indicated that the harvest index $(\mathrm{HI})$ did not respond significantly $(P<0.05)$ to rates of the NPS fertilizer and its interaction with $\mathrm{KCl}$ (Table 9). However, K fertilizer had a significant effect on HI (Table 9). The maximum and minimum $\mathrm{HI}$ was recorded at 50 and
$0 \mathrm{~kg} \cdot \mathrm{ha}^{-1} \mathrm{KCl}$, respectively (Table 8), while $\mathrm{K}$ applications between 25 and $75 \mathrm{~kg} \cdot \mathrm{ha}^{-1} \mathrm{KCl}$ were statically at par.

3.4.9. Agronomic Efficiency. Agronomic efficiency of wheat exhibited significant $(P<0.05)$ changes due to NPS and $\mathrm{KCl}$ and their interaction effects (Tables 5 and 9). The highest agronomic efficiency $\left(19.5 \mathrm{~kg} \cdot \mathrm{kg}^{-1}\right)$ was recorded at the rate of $150 \mathrm{~kg} \cdot \mathrm{ha}^{-1} \mathrm{NPS}$ and $50 \mathrm{~kg} \cdot \mathrm{ha}^{-1} \mathrm{KCl}$. However, the least agronomic efficiency $\left(2.0 \mathrm{~kg} \cdot \mathrm{kg}^{-1}\right)$ was recorded from plots which received $25 \mathrm{~kg} \cdot \mathrm{ha}^{-1} \mathrm{KCl}$ without NPS (Table 10). The data showed an increasing trend in agronomic efficiency of wheat with increasing levels of NPS and K up to $150 \mathrm{~kg} \cdot \mathrm{ha}^{-1}$ NPS and $50 \mathrm{~kg} \cdot \mathrm{ha}^{-1} \mathrm{KCl}$ above which the efficiency was reduced. This might indicate that the application of balanced nutrient containing NPS and K up to the optimum level has a positive contribution towards increasing the crop efficiency of nutrient uptake and conversion to the grain yield. Above the optimum level, decline of the efficiency at the highest level of nutrient application might be attributed to reduced uptake rate per unit of applied nutrients. According to Croswell and Godwin [69], high agronomic efficiency would be obtained if the yield increment per unit applied is high. Fageria and Baligar [70] also stated that high agronomic efficiency is obtained if the yield increment per unit nutrient applied is high because of reduced losses and increased uptake. 
TABLE 7: Total number of tillers per plant, number of grains per spike, thousand-grain weight, above-ground biomass, and grain yield of wheat as affected by the interaction effect of NPS and $\mathrm{KCl}$ fertilizer rates at Sodo Zuria, Wolaita Zone, Southern Ethiopia, during 2016.

\begin{tabular}{|c|c|c|c|c|c|}
\hline & & & $\left(\mathrm{kg} \cdot \mathrm{ha}^{-1}\right)$ & & \\
\hline & NPS $\left(\mathrm{kg} \cdot \mathrm{ha}^{-1}\right)$ & 0 & 25 & 50 & 75 \\
\hline & 0 & $1.33^{\mathrm{i}}$ & $2.50^{\mathrm{h}}$ & $3.0^{\mathrm{fgh}}$ & $2.66^{\mathrm{gh}}$ \\
\hline & 50 & $3.20^{\mathrm{efgh}}$ & $3.16^{\text {efgh }}$ & $4.23^{\mathrm{c}}$ & $3.36^{\text {cdefgh }}$ \\
\hline TTNPP & 100 & $3.30^{\text {cdefgh }}$ & $3.50^{\text {cdefg }}$ & $5.26^{\mathrm{b}}$ & $3.23^{\mathrm{defgh}}$ \\
\hline & 150 & $3.70^{\text {cdef }}$ & $3.87^{\mathrm{cdef}}$ & $6.60^{\mathrm{a}}$ & $3.90^{\text {cdef }}$ \\
\hline & 200 & $3.40^{\text {cdefgh }}$ & $4.10^{\text {cde }}$ & $4.20^{\mathrm{cd}}$ & $3.93^{\mathrm{cdef}}$ \\
\hline LSD (0.05) & & 0.97 & & & \\
\hline CV (\%) & & 16.2 & & & \\
\hline & 0 & $16.3^{1}$ & $22.0^{\mathrm{k}}$ & $28.3^{\text {hi }}$ & $24.0^{\mathrm{jk}}$ \\
\hline & 50 & $27.7^{\mathrm{ij}}$ & $31.7^{\mathrm{fgh}}$ & $36.3^{\mathrm{de}}$ & $31.0^{\mathrm{ghi}}$ \\
\hline NGPS (g) & 100 & $31.7^{\mathrm{fgh}}$ & $37.7^{\mathrm{cd}}$ & $45.7^{\mathrm{b}}$ & $36.0^{\mathrm{de}}$ \\
\hline & 150 & $36.0^{\mathrm{de}}$ & $40.7^{\mathrm{c}}$ & $50.7^{\mathrm{a}}$ & $39.0^{\mathrm{cd}}$ \\
\hline & 200 & $32.7^{\text {efg }}$ & $35.3^{\mathrm{def}}$ & $39.0^{\mathrm{cd}}$ & $37.3^{\mathrm{cd}}$ \\
\hline LSD (0.05) & & 3.82 & & & \\
\hline CV (\%) & & 6.82 & & & \\
\hline & 0 & $27.333^{\mathrm{g}}$ & $37.33^{\text {ef }}$ & $39.66^{\mathrm{def}}$ & $35.67^{\mathrm{f}}$ \\
\hline & 50 & $42.33^{\text {cde }}$ & $43.33 \mathrm{~cd}$ & $41.67^{\text {cde }}$ & $44.33^{\mathrm{bcd}}$ \\
\hline TKW (g) & 100 & $43.33^{\mathrm{cd}}$ & $44.33^{\mathrm{bcd}}$ & $49.33^{\mathrm{b}}$ & $45.33^{\mathrm{bc}}$ \\
\hline & 150 & $42.00^{\text {cde }}$ & $44.00^{\mathrm{bcd}}$ & $56.33^{\mathrm{a}}$ & $42.00^{\text {cde }}$ \\
\hline & 200 & $44.67^{\mathrm{bcd}}$ & $44.33^{\mathrm{bcd}}$ & $44.00^{\mathrm{bcd}}$ & $43.33^{\mathrm{cd}}$ \\
\hline LSD (0.05) & & 5.48 & & & \\
\hline CV (\%) & & 7.76 & & & \\
\hline & 0 & $1.13^{\mathrm{g}}$ & $1.27^{\mathrm{g}}$ & $2.80^{\mathrm{f}}$ & $2.73^{\mathrm{f}}$ \\
\hline & 50 & $2.57^{\mathrm{f}}$ & $3.10^{\mathrm{f}}$ & $4.53^{\mathrm{e}}$ & $4.67^{\mathrm{e}}$ \\
\hline $\operatorname{AGBM}\left(\mathrm{t} \cdot \mathrm{ha}^{-1}\right)$ & 100 & $4.83^{\mathrm{e}}$ & $5.07^{\mathrm{e}}$ & $6.80^{\mathrm{c}}$ & $6.90^{c}$ \\
\hline & 150 & $5.80^{\mathrm{d}}$ & $6.67^{\mathrm{c}}$ & $9.57^{\mathrm{a}}$ & $8.10^{\mathrm{b}}$ \\
\hline & 200 & $6.60^{c}$ & $6.80^{\mathrm{c}}$ & $7.53^{\mathrm{b}}$ & $6.80^{c}$ \\
\hline LSD (0.05) & & 0.62 & & & \\
\hline CV (\%) & & 7.28 & & & \\
\hline & 0 & $0.44^{j}$ & $0.49^{j}$ & $1.19^{\mathrm{i}}$ & $1.12^{\mathrm{i}}$ \\
\hline & 50 & $1.02^{\mathrm{i}}$ & $1.24^{\mathrm{i}}$ & $1.88^{\mathrm{h}}$ & $1.99^{\mathrm{gh}}$ \\
\hline GY $\left(\mathrm{t} \cdot \mathrm{ha}^{-1}\right)$ & 100 & $1.99^{\mathrm{gh}}$ & $2.23^{\mathrm{fg}}$ & $2.98^{\mathrm{cd}}$ & $2.87^{\mathrm{d}}$ \\
\hline & 150 & $2.29^{\mathrm{fg}}$ & $2.89^{\mathrm{d}}$ & $4.34^{\mathrm{a}}$ & $3.44^{\mathrm{b}}$ \\
\hline & 200 & $2.49^{\mathrm{ef}}$ & $2.72^{\mathrm{de}}$ & $3.25^{\mathrm{bc}}$ & $2.86^{\mathrm{d}}$ \\
\hline LSD (0.05) & & 0.33 & & & \\
\hline CV (\%) & & 9.01 & & & \\
\hline
\end{tabular}

LSD: least significant difference at the 5\% level; CV: coefficient of variation; means in columns followed by the same letters are not significantly different at the $5 \%$ level of significance; TTNPP: total number of tillers per plant; TKW: thousand-grain weights; NGPS: number of grains per spike; AGBM: above-ground biomass; GY: grain yield.

3.5. Partial Budget Analysis. The result showed that highest net benefit $\left(36,033.4\right.$ birr.ha $\left.{ }^{-1}\right)$ was obtained from $150 \mathrm{~kg} \cdot \mathrm{ha}^{-1} \mathrm{NPS}$ and $50 \mathrm{~kg} \cdot \mathrm{ha}^{-1} \mathrm{KCl}$, whereas the least net benefit ( 3920 birr.ha ${ }^{-1}$ ) was obtained from the unfertilized treatment (Table 11). The net return was about 8.9 -fold higher than that of the control. Accordingly, the result showed that the highest MRR (i.e., 4252.6\%) was obtained from the application of $150 \mathrm{~kg} \cdot \mathrm{ha}^{-1} \mathrm{NPS}$ and $50 \mathrm{~kg} \cdot \mathrm{ha}^{-1} \mathrm{KCl}$; and it was followed by MRR (i.e., 2234.8\%) recorded from $100 \mathrm{~kg} \cdot \mathrm{ha}^{-1} \mathrm{NPS}$ and $50 \mathrm{~kg} \cdot \mathrm{ha}^{-1} \mathrm{KCl}$ (Table 7). Therefore, the 
TABLE 8: Productive tillers per plant of wheat as affected by NPS and K fertilizer rates at Sodo Zuria, Wolaita Zone, Southern Ethiopia, during 2016.

\begin{tabular}{|c|c|c|}
\hline Fertilizer $\left(\mathrm{kg} \cdot \mathrm{ha}^{-1}\right)$ & $\begin{array}{c}\text { Productive tillers } \\
\text { No. }\end{array}$ & $\begin{array}{l}\text { Harvest index (\%) } \\
\text { No. }\end{array}$ \\
\hline \multicolumn{3}{|l|}{ NPS } \\
\hline 0 & $1.91^{\mathrm{d}}$ & 40.25 \\
\hline 50 & $2.87^{\mathrm{c}}$ & 41.00 \\
\hline 100 & $3.53^{\mathrm{b}}$ & 42.58 \\
\hline 150 & $4.57^{\mathrm{a}}$ & 42.75 \\
\hline 200 & $3.69^{\mathrm{b}}$ & 40.75 \\
\hline LSD (0.05) & 0.17 & NS \\
\hline \multicolumn{3}{|l|}{$\mathrm{KCl}$} \\
\hline 0 & $3.01^{\mathrm{d}}$ & $39.40^{\mathrm{b}}$ \\
\hline 25 & $3.18^{c}$ & $41.13^{\mathrm{ab}}$ \\
\hline 50 & $3.64^{\mathrm{a}}$ & $43.27^{\mathrm{a}}$ \\
\hline 75 & $3.42^{\mathrm{b}}$ & $42.07^{\mathrm{a}}$ \\
\hline LSD (0.05) & 0.15 & 3.59 \\
\hline CV (\%) & 6.14 & 7.42 \\
\hline
\end{tabular}

LSD (0.05): least significant difference at the $5 \%$ level; CV: coefficient of variation; NS: nonsignificant. Means in the column followed by the same letters are not significantly different at the $5 \%$ level of significance.

TABLE 9: Mean squares of ANOVA for grain yield, straw yield, and above-ground dry biomass of wheat.

\begin{tabular}{|c|c|c|c|c|c|c|}
\hline Source variance & DF & AGDBM & GY & SY & $\mathrm{HI}$ & $\mathrm{AE}$ \\
\hline REP & 2 & 2.0162 & 0.3077 & 2.2167 & 2.2167 & 9.589 \\
\hline NPS & 3 & $64.457^{*}$ & $11.934^{*}$ & $15.3167^{\mathrm{NS}}$ & $15.3167^{\mathrm{NS}}$ & $92.027^{*}$ \\
\hline $\mathrm{K}$ & 4 & $14.578^{*}$ & $3.663^{*}$ & $39.9111^{*}$ & $39.9111^{*}$ & $162.74^{*}$ \\
\hline $\mathrm{NPS}^{*} \mathrm{~K}$ & 12 & $0.8799^{*}$ & 0.1929* & $3.9944^{\mathrm{NS}}$ & $3.9944^{\mathrm{NS}}$ & $23.37^{*}$ \\
\hline Error & 38 & 0.1442 & 0.0388 & 9.4623 & 9.4623 & 3.622 \\
\hline
\end{tabular}

NS and $*$ : nonsignificant and significant at 5\%. SY: straw yield; GY: grain yield; AGDBM: above-ground dry biomass; HI: harvest index; AE: agronomic efficiency.

TABLE 10: The interaction effect of NPS and K on straw yield (SY) ( $t /$ ha) and agronomic efficiency (AE) of bread wheat at Sodo Zuria, Wolaita Zone, Southern Ethiopia, during 2016.

\begin{tabular}{|c|c|c|c|c|}
\hline \multirow{2}{*}{$\begin{array}{l}\text { Fertilizer }\left(\mathrm{kg} \cdot \mathrm{ha}^{-1}\right) \\
\text { NPS }\end{array}$} & \multicolumn{4}{|c|}{$\mathrm{KCl}\left(\mathrm{kg} \cdot \mathrm{ha}^{-1}\right)$} \\
\hline & 0 & 25 & 50 & 75 \\
\hline \multicolumn{5}{|l|}{ SY $\left(\mathrm{t} \mathrm{ha}^{-1}\right)$} \\
\hline 0 & $0.64^{\mathrm{k}}$ & $0.74^{\mathrm{k}}$ & $1.04^{\mathrm{jk}}$ & $0.70^{\mathrm{k}}$ \\
\hline 50 & $1.56^{\mathrm{ij}}$ & $1.86^{\mathrm{hi}}$ & $2.35^{\mathrm{gh}}$ & $2.4^{\mathrm{fgh}}$ \\
\hline 100 & $2.98^{\mathrm{def}}$ & $2.82^{\mathrm{efg}}$ & $3.28^{\text {cde }}$ & $3.3^{\text {cde }}$ \\
\hline 150 & $3.43^{\mathrm{cd}}$ & $4.03^{\mathrm{b}}$ & $5.13^{\mathrm{a}}$ & $3.8^{\mathrm{bc}}$ \\
\hline 200 & $4.10^{\mathrm{b}}$ & $3.77^{\mathrm{bc}}$ & $3.85^{\mathrm{bc}}$ & $3.71^{b c}$ \\
\hline LSD (0.05) & & 0.59 & & \\
\hline CV (\%) & & 12.9 & & \\
\hline \multicolumn{5}{|l|}{$\mathrm{AE}\left(\mathrm{kg} \cdot \mathrm{kg}^{-1}\right)$} \\
\hline 0 & - & $2.000^{\mathrm{h}}$ & $15.00^{\mathrm{bc}}$ & $9.02^{\mathrm{g}}$ \\
\hline 50 & $11.53^{\mathrm{defg}}$ & $10.68^{\mathrm{fg}}$ & $14.40^{\mathrm{bcd}}$ & $12.4^{\text {cdef }}$ \\
\hline 100 & $15.50^{\mathrm{bc}}$ & $15.413^{\mathrm{bc}}$ & $16.96^{\mathrm{ab}}$ & $13.90^{\mathrm{bcde}}$ \\
\hline 150 & $12.37^{\text {cdef }}$ & $14.01^{\text {bcde }}$ & $19.48^{\mathrm{a}}$ & $13.94^{\text {bcde }}$ \\
\hline 200 & $10.28^{\mathrm{fg}}$ & $10.16^{\mathrm{fg}}$ & $11.25^{\mathrm{efg}}$ & $8.81^{\mathrm{g}}$ \\
\hline LSD (0.05) & & 3.15 & & \\
\hline CV (\%) & & 16.05 & & \\
\hline
\end{tabular}

LSD: least significant difference at the 5\% level; CV: coefficient of variation; means in columns followed by the same letters are not significantly different at the $5 \%$ level of significance; SY: straw yield; AE: agronomic efficiency. 
TABLE 11: Partial budget analysis for NPS fertilizer rate and K fertilizer application.

\begin{tabular}{|c|c|c|c|c|c|c|c|}
\hline $\begin{array}{l}\text { NPS and } \mathrm{KCl} \text { rate } \\
\left(\mathrm{kg} \mathrm{ha}^{-1}\right)\end{array}$ & $\begin{array}{c}\mathrm{GY} \\
\left(\mathrm{t} \cdot \mathrm{ha}^{-1}\right)\end{array}$ & $\begin{array}{c}\mathrm{ADY} \\
\left(\mathrm{t} \cdot \mathrm{ha}^{-1}\right)\end{array}$ & $\begin{array}{l}\text { Net benefits } \\
\text { (birr.ha }^{-1} \text { ) }\end{array}$ & $\begin{array}{c}\text { Total variable cost } \\
\text { (birr) }\end{array}$ & $\begin{array}{l}\text { Marginal net } \\
\text { benefit (birr) }\end{array}$ & $\begin{array}{l}\text { Marginal variable } \\
\text { cost (birr) }\end{array}$ & $\begin{array}{c}\text { MRR } \\
(\%)\end{array}$ \\
\hline 0,0 & 0.43 & 0.392 & 3920 & - & - & - & - \\
\hline 0,25 & 0.48 & 0.437 & 4370 & 304.28 & 450 & 304.28 & 147.9 \\
\hline 0,50 & 1.19 & 1.067 & 10670 & 608.57 & 6300 & 304.28 & 2070.5 \\
\hline 0,75 & 1.12 & 1.0019 & 10019 & 912.8 & -651 & 304.28 & -213.9 \\
\hline 50,0 & 1.01 & 0.9119 & 9119 & 776 & - & - & - \\
\hline 50,25 & 1.23 & 1.1097 & 11097 & 1080.28 & 1978 & 304.28 & 650 \\
\hline 50,50 & 1.88 & 1.689 & 16890 & 1384.57 & 5793 & 304.28 & 1903.8 \\
\hline 50,75 & 1.99 & 1.791 & 17910 & 1688.85 & 1020 & 304.28 & 335.2 \\
\hline 100,0 & 1.99 & 1.791 & 17910 & 1552 & - & - & - \\
\hline 100,25 & 2.23 & 2.004 & 20040 & 1856.28 & 2130 & 304.28 & 700 \\
\hline 100,50 & 2.98 & 2.684 & 26840 & 2160.57 & 6800 & 304.28 & 2234.8 \\
\hline 100,75 & 2.87 & 2.583 & 25830 & 2464.85 & -1010 & 304.28 & -331.9 \\
\hline 150,0 & 2.29 & 2.0603 & 20603 & 2328 & - & - & - \\
\hline 150,25 & 2.89 & 2.603 & 26030 & 2632.28 & 5427 & 304.28 & 1783.5 \\
\hline 150,50 & 4.33 & 3.897 & 38970 & 2932.28 & 12940 & 304.28 & 4252.6 \\
\hline 150,75 & 3.44 & 3.09 & 30900 & 3240.85 & -8000 & 304.28 & -2652.1 \\
\hline 200,0 & 2.49 & 2.639 & 22430 & 3104 & - & & - \\
\hline 200,25 & 2.72 & 2.448 & 24480 & 3408.28 & 2050 & 304.28 & 673.7 \\
\hline 200,50 & 3.25 & 2.925 & 29250 & 3712.57 & 4770 & 304.28 & 1567.6 \\
\hline 200,75 & 2.86 & 2.574 & 25740 & 4016.85 & -3510 & 304.28 & -1153.5 \\
\hline
\end{tabular}

GY: grain yield; ADY: adjusted grain yield; MRR: marginal rate of return.

application of $150 \mathrm{~kg} \cdot \mathrm{ha}^{-1} \mathrm{NPS}$ and $50 \mathrm{~kg} \cdot \mathrm{ha}^{-1} \mathrm{KCl}$ followed by $100 \mathrm{~kg} \cdot \mathrm{ha}^{-1} \mathrm{NPS}$ and $50 \mathrm{~kg} \cdot \mathrm{ha}^{-1} \mathrm{KCl}$ was economically profitable.

\section{Conclusion}

Based on the results obtained on the effects of different fertilizing rates in bread wheat, the following conclusions may be drawn. The multinutrient deficiencies in the study area could be addressed through balanced nutrition of NPKS. Consequently, fertilization of wheat with $150 \mathrm{~kg} \cdot \mathrm{ha}^{-1} \mathrm{NPS}$ and $50 \mathrm{~kg} \cdot \mathrm{ha}^{-1} \mathrm{KCl}$ produced the highest grain yield, economic return, and agronomic efficiency. Regardless of higher soil exchangeable $\mathrm{K}$ in the present study, the response of wheat to the $\mathrm{K}$ fertilizer justified the presence of $\mathrm{K}$ inadequacy probably from the competition of other cations such as $\mathrm{Mg}$. Moreover, individual effects of $\mathrm{N}, \mathrm{P}$, and $S$ should be further investigated on the wheat crop as they were applied in the blended form.

\section{Data Availability}

The data presented in this manuscript are available from the corresponding author upon request.

\section{Conflicts of Interest}

The authors declare that they have no conflicts of interest.

\section{Authors' Contributions}

Tigist Tesfaye collected, analyzed, and interpreted the data. Fanuel Laekemariam and Abera Habte drafted the manuscript. All authors read and approved the final manuscript.

\section{Acknowledgments}

The authors' appreciation goes to Areka Agricultural Research Center, Southern Ethiopia, for allowing them to use the land for this experiment.

\section{References}

[1] M. Demeke and F. Di Marcantonio, Analysis of Incentives and Disincentives for Wheat in Ethiopia, Technical Notes Series, MAFAP, FAO, Rome, Italy, 2013.

[2] CSA (Central Statistical Agency), "Agricultural sample survey report on area and production of major crops for private peasant holdings, Maher season," Statistical Bulletin 584, Vol. I, CSA (Central Statistical Agency), Addis Ababa, Ethiopia, 2017.

[3] T. Mideksa, T. Letta, T. Bayisa et al., "Bread wheat varietal development and release in Southeastern Highlands of Ethiopia," American Journal of Biological and Environmental Statistics, vol. 4, no. 1, pp. 15-19, 2018.

[4] EARO (Ethiopian Agricultural Research Organization), Directory of Released Crop Varieties and Their Recommended Cultural Practices, EARO (Ethiopian Agricultural Research Organization), Addis Ababa, Ethiopia, 2004.

[5] M. Mann and J. Warner, "Ethiopian wheat yield and yield gap estimation: a spatially explicit small area integrated data approach," Field Crops Research, vol. 201, pp. 60-74, 2017.

[6] M. Abbas, A. D. Sheikh, and H. M. Sabir, "Factors responsible for low wheat productivity in in central Punjab," Pakistan Journal Agricultural Sciences, vol. 42, p. 35, 2005.

[7] E. Teklu and T. Hailemariam, "Agronomic and economic efficiency of manure and urea fertilizers use on vertisols in Ethiopian highlands," Agricultural Sciences in China, vol. 8, no. 3, pp. 352-360, 2009.

[8] EthioSIS (Ethiopian Soil Information System), Soil Analysis Report Agricultural Transformation Agency, EthioSIS (Ethiopian Soil Information System), Addis Abeba, Ethiopia, 2013. 
[9] L. Esayas, Effect of Blended Fertilizers on Yield and Yield Traits of Durum Wheat (Triticum Turgidum L. Var. Durum) Varieties in Ada District, Central Ethiopia, M.Sc. thesis, The School of Graduate Studies, Alemaya University, Dire Dawa, Ethiopia, 2015.

[10] J. C. J. Wu, X. S. Guo, X. U. Yang, and Y. Q. Wang, "Effects of grain yield and quality of strong gluten wheat and interaction in combined application of nitrogen and potassium," Journal of Anhui Agricultural University, vol. 33, no. 3, pp. 302-305, 2006.

[11] A. Doberman and T. Fairhurst, "Rice: nutrient disorder and nutrient management," Hand Book Series, p. 191, Potash and Phosphate Institute of Canada and International Rice Research Institute, Saskatoon, Canada, 2000.

[12] D. Damene, "Yield response of bread wheat (Triticum aestivum L.) to applied levels of $\mathrm{N}$ and $\mathrm{P}$ fertilizers on nitosol of Dawro Zone, South Western Ethiopia," M.Sc. thesis, The School of Graduate Studies, Alemaya University, Dire Dawa, Ethiopia, 2003.

[13] B. Haileselassie, "Effects of mineral nitrogen and phosphorus fertilizers on yield and nutrient utilization of bread wheat (Tritcum aestivum) on the sandy soils of Hawzen District, northern Ethiopia," Agriculture, Forestry and Fisheries, vol. 3, no. 3, pp. 189-198, 2014.

[14] F. Laekemariam, K. K. T. Mamo, K. Kibret, T. Mamo, and H. Shiferaw, "Accounting spatial variability of soil properties and mapping fertilizer types using geostatistics in southern Ethiopia," Communications in Soil Science and Plant Analysis, vol. 49 , no. 1 , pp. 124-137, 2018a.

[15] F. Laekemariam, K. Kibret, T. Mamo, and H. Gebrekidan, "Soil-plant nutrient status and their relations in maizegrowing fields of Wolaita zone, southern Ethiopia," Communications in Soil Science and Plant Analysis, vol. 47, no. 11, pp. 1343-1356, 2016.

[16] F. Laekemariam, K. Kibret, and H. Shiferaw, "Potassium (K)to-magnesium $(\mathrm{Mg})$ ratio, its spatial variability and implications to potential Mg-induced $\mathrm{K}$ deficiency in nitisols of southern Ethiopia," Agriculture \& Food Security, vol. 7, no. 1, p. 13, 2018 b.

[17] A. Ashenafi, E. Abayneh, and B. Sheleme, "Characterizing soils of Delbo Wogene watershed, Wolaita zone, southern Ethiopia for planning appropriate land management," Journal of Soil Science and Environmental Management, vol. 1, no. 8, pp. 184-199, 2010.

[18] MoARD (Minister of Agriculture and Rural Development), Crop Variety Registration, MoARD (Minister of Agriculture and Rural Development), Addis Ababa, Ethiopia, 2012.

[19] G. J. Bouyoucous, "Hydrometer method improved for making particle size analyses of soils," Agronomy Journal, vol. 54, pp. 464-465, 1962.

[20] L. P. Van Reeuwijk, Procedures for Soil Analysis, International Soil Reference Center, Wageningen, The Netherlands, 3rd edition, 1992.

[21] A. Walkley and I. A. Black, “An examination of the degtjareff method for determining soil organic matter, and a proposed modification of the chromic acid titration method," Soil Science, vol. 37, no. 1, pp. 29-38, 1934.

[22] M. L. Jackson, Soil Chemical Analysis, Practice Hall of India, New Delhi, India, 1967.

[23] S. R. Olsen, C. W. Cole, F. S. Watanabe, and L. A. Dean, Estimation of Available Phosphorous in Soils by Extraction with Sodium Bicarbonate Circular 939, US Department of Agriculture, Washington, DC, USA, 1954.
[24] FAO (Food and Agriculture Organization of the United Nations), Plant Nutrition for Food Security: A Guide for Integrated Nutrient Management, Vol. 16, FAO, Fertilizer and plant Nutrition Bulletin, Rome, Italy, 2006.

[25] V. B. Allen and D. J. Pilbeam, Hand Book of Plant Nutrition, Taylor and Fransis Publishing Group, Milton Park, UK, 2007.

[26] H. D. Chapman, "Cation exchange capacity by ammonium saturation," in Method of Soil Analysis, C. A. Black, L. E. Ensminger, and F. E. Clark, Eds., vol. 9, pp. 891-901, American Society of Agronomy, Madison WI, USA, 1965.

[27] M. J. Mulvaney and P. Devkota, Adjusting Crop Yield to a Standard Moisture Content, University of Florida, IFAS Extension. SS-AGR-443, Gainesville, FL, USA, 2020.

[28] T. R. Wheeler, T. D. Hong, R. H. Ellis, G. R. Batts, J. I. L. Morison, and P. Hadley, "The duration and rate of grain growth, and harvest index, of wheat (Triticum aestivum L.) in response to temperature and C02," Journal of Experimental Botany, vol. 47, no. 298, p. 623, 1996.

[29] V. C. Baligar, N. K. Fageria, and Z. L. He, "Nutrient use efficiency in plants," Communication in Soil Science and Plant Analysis, vol. 32, no. 7-8, pp. 921-950, 2001.

[30] SAS Institute Inc, SAS/STAT Users Guide, SAS software, Cary, NC, USA, 8 edition, 2002.

[31] CIMMYT (International Maize and Wheat Improvement Center), An Economic Training Manual: From Agronomic Data Recordation, CYMMT, Mexico City, MX, USA, 1988.

[32] P. Hazelton and B. Murphy, Interpreting Soil Test Results. What Do All the Numbers Mean?, CSIRO Publishing, Clayton, Australia, 2007.

[33] J. R. Landon, Booker Tropical Soil Manual: A Handbook for Soil Survey and Agricultural Land Evaluation in the Tropics and Sub-tropics, Longman Scientific and Technical, Essex, NY, USA, 1991.

[34] A. Cottenie, Soil and Plant Testing as a Basis of Fertilizer Recommendations, FAO Soil Bulletin 38/2. Food and Agriculture Organization of the United Nations, Rome, Italy, 1980.

[35] M. T. Jan and S. Khan, "Response of wheat yield components to type of N-fertilizer, their levels and application time," Pakistan Journal of Biological Sciences, vol. 3, no. 8, pp. 1227-1230, 2000.

[36] N. C. Brady and R. R. Weil, The Nature and Properties of Soils, Pearson Education Inc., Upper Saddle River, NJ, USA, 13th edition, 2002.

[37] P. Marschner, Mineral Nutrition of Higher Plants, Academic Press, London, UK, 3rd edition, 2012.

[38] D. D. Lakudzala, "Potassium response in some Malawi soils," International Letters of Chemistry, Physics and Astronomy, vol. 13, no. 2, pp. 175-181, 2013.

[39] H. B. Liebersbach, G. Stein, and N. Claassen, "Roots regulate ion transport in the rhizosphere to counteract reduced mobility in dry soil," Plant Soil, vol. 260, no. 1-2, pp. 79-88, 2004.

[40] H. Hailu, T. Mamo, R. Keskinen, E. Karltun, H. Gebrekidan, and T. Bekele, "Soil fertility status and wheat nutrient content in vertisol cropping systems of central highlands of Ethiopia," Agriculture \& Food Security, vol. 4, no. 1, p. 19, 2015.

[41] M. Y. Amanullah, S. K. Khalil, M. T. Jan, and A. Z. Khan, "Phenology, growth, and grain yield of maize as influenced by foliar applied urea at different growth stages," Journal of Plant Nutrition, vol. 33, pp. 71-79, 2010.

[42] M. Ayub, M. A. Nadeem, M. S. Sharar, and M. Mahmud, "Response of maize (Zea mays L.) to different leveks of nitrogen and potassium fertilizer," Asian Journal of Plant Sciences, vol. 4, no. 1, pp. 352-354, 2002. 
[43] M. Maqsood, A. M. Abide, A. Iqbal, and M. I. Hussain, "Effect of variable rate of nitrogen and phosphorus on growth and yield of maize (golden)," Online Journal of Biological Sciences, vol. 1, pp. 19-20, 2001.

[44] M. A. Khan, I. Hussain, and M. S. Baloch, "Wheat yield potential current status and future strategies," Pakistan Journal of Biological Science, vol. 3, pp. 82-86, 2000.

[45] M. Järvan, L. Edesi, and A. Adamson, "Effect of sulphur fertilization on grain yield and yield components of winter wheat," Acta Agriculturae Scandinavica, Section B - Soil \& Plant Science, vol. 62, no. 5, pp. 401-409, 2012.

[46] J. Ara, J. A. Mahmud, M. S. Ryad, F. Nur, S. Sarkar, and M. M. Islam, "Response of seed yield contributing characters and seed quality of rapeseed (Brassica campestris L.) to nitrogen and boron," Applied Scientific Reports, vol. 1, pp. 5-10, 2014.

[47] Z. Q. Jiang, C. N. Feng, L. L. Huang, W. S. Guo, X. K. Zhu, and Y. X. Peng, "Effects of phosphorus application on dry matter production and phosphorus uptake in wheat," Plant Nut. \& Fert. Sci.vol. 12, no. 5, pp. 628-634, 2006.

[48] S. L. Tisdale, W. L. Nelson, J. D. Beaton, J. L. Havlin, "Soil and fertilizer potassium," in Soil Fertility and Fertilizers, pp. 230-265, Prentice-Hall, New Delhi, India, 5th edition, 2002.

[49] A. H. Jasim, "Effect of soil sulfur fertilizer and some foliar fertilizers on growth and yield of Broccoli in saline soil," Annals of West University of Timisoara, ser. Biology, vol. XVIII, no. 2, pp. 123-130, 2015.

[50] A. L. Malghani, A. U. Malik, A. Sattar, F. Hussain, G. Abbas, and J. Hussain, "Response of growth and yield of wheat to NPK fertilizer," Science International (Lahore), vol. 24, pp. 185-189, 2010.

[51] G. M. Laghari, F. C. Oad, S. D. Tunio et al., "Growth yield and nutrient uptake of various wheat cultivars under different fertilizer regimes," Sarhad Journal of Agriculture, vol. 26, no. 4, pp. 489-497, 2010.

[52] V. Liakas, V. Rauckis, and V. Paltanaviius, "Influence of phosphorus and potash fertilizers on germination, tillering and overwintering of winter wheat," Mokslo Darbai, vol. 74, pp. 3-12, 2001.

[53] M. A. Tahir, M. A. G. Rahmatullah, T. Aziz, and M. Imran, "Response of wheat and oat crops to potassium application and artificial irrigation with canal water," Pakistan Journal of Agricultural Sciences, vol. 40, no. 3-4, pp. 114-118, 2003.

[54] G. Gezu, "Yield and quality response of bread wheat varieties to rate and time of nitrogen fertilizer application in Kulumsa, South Eastern Ethiopia," M.Sc. thesis, School of Graduate Studies of Alemaya University, Dire Dawa, Ethiopia, 2003.

[55] M. A. Baque, M. A. Karim, A. Hamid, and H. Tetsushi, "Effects of fertilizer potassium on growth, yield and nutrient uptake of wheat (Triticum aestivum) under water stress conditions," South Pacific Studies, vol. 27, no. 1, pp. 25-35, 2006.

[56] V. D. Fageria, "Nutrient interactions in crop plants," Journal of Plant Nutrition, vol. 24, no. 8, pp. 1269-1290, 2001.

[57] Z. Y. Zhang, K. G. Sun, A. Y. Lu, and X. B. Zhang, "Study on the effect of $S$ fertilizer application on crops and the balance of S in soil," Journal of Agricultural Science, vol. 5, pp. 25-27, 1999.

[58] M. A. Bahmanyar and G. A. Ranjbar, "The Role of potassium in improving growth indices and increasing amount of grain nutrient elements of wheat cultivars," Journal of Applied Sciences, vol. 8, no. 7, pp. 1280-1285, 2008.
[59] H. Brhane, T. Mamo, and K. Teka, "Optimum potassium fertilization level for growth, yield and nutrient uptake of wheat (Triticum aestivum) in vertisols of northern Ethiopia," Cogent Food \& Agriculture, vol. 3, no. 1, Article ID 1347022, 2017.

[60] H. Ali, S. Ahmad, H. Ali, and F. S. Hassan, "Impact of nitrogen application on growth and productivity of wheat (Triticum aestivum L.)," Journal of Agriculture and Social Sciences, vol. 1, no. 3, pp. 216-218, 2005.

[61] M. Arif, M. A. Chohan, S. Ali, R. Gul, and S. Khan, "Response of wheat to foliar application of nutrients," Journal of Agriculture \& Biological Science, vol. 1, pp. 30-34, 2006.

[62] A. Asghar, A. Ali, W. H. Syed, M. Asif, T. Khaliq, and A. A. Abid, "Growth and yield of maize cultivars affected by NPK application in different proportion," Pakistan Journal of Sciences, vol. 62, no. 4, pp. 211-216, 2010.

[63] T. Amsal, D. G. Tanner, T. Taye, and M. Chanyalew, "Agronomic and economic evaluation of the on farm $\mathrm{N}$ and $\mathrm{P}$ response of bread wheat grown on two contrasting soil types in Central Ethiopia," in Proceedings of the 11th Regional Wheat Workshop for Central, Eastern and Southern Africa, p. 329, CIMMYT, Addis Ababa, Ethiopia, September 2000.

[64] B. Kara, "Phosphorus use efficiency of some bread wheat cultivars," Research on Crops, vol. 14, no. 2, pp. 389-394, 2013.

[65] N. G. Riley, F. J. Zhao, and S. P. McGrath, "Availability of different forms of sulfur Fertilizers to wheat and oilseed rape," Plant and Soil, vol. 222, no. 1/2, pp. 139-147, 2000.

[66] K. H. Shah, S. H. Siddiqui, M. Y. Memon, M. Aslam, M. Imtiaz, and P. Khan, "Performance of fertigation technique for $\mathrm{p}$ usage efficiency in wheat," Asian Journal of Plant Sciences, vol. 2, no. 15, pp. 1088-1091, 2003.

[67] K. Abreha, B. Kahsa, and H. Semere, "Determination of critical level and requirement factor of soil phosphorus: a base for a soil test-based phosphorus fertilizer recommendation," Unpublished report, 2008.

[68] R. L. Tiwari, S. Sanjaykumar Kumar, and D. Dash, "S status of soil and crops and response of crops to doses and sources of S in eastern Uttar Pardesh," Fertilizer News, vol. 48, pp. 33-38, 2003.

[69] E. T. Croswell and D. C. Godwin, Principles of Plant Nutrition, K. Mengel and E. A. Kirkby, Eds., Panima Publishing Corporation, New Delhi, India, 1984.

[70] N. K. Fageria and V. C. Baligar, "Enhancing nitrogen use efficiency in crop plants," Advances in Agronomy, vol. 88, pp. 97-185, 2005. 